\title{
ANALISIS PENERAPAN BALANCED SCORECARD SEBAGAI ALAT PENGUKURAN KINERJA (Studi Kasus: di BPRS Artha Surya Barokah Semarang)
}

\author{
Oleh : \\ Ayuningtyas Adiputri \\ Andwiani Sinarasri \\ Program Studi Akuntansi \\ Fakultas Ekonomi \\ Universitas Muhammadiyah Semarang
}

\begin{abstract}
The economic crisis a few years ago to make economic conditions in Indonesia have made great progress, so that requires leaders and company management to improve competitiveness by providing the best services for its customers in order to survive. One of the company's goal is to support their survival to earn profits. The company's main goal can be achieved if the maximum performance of the company and work well , because of the success and the success of an enterprise is the ability to generate profit and expand its business .
\end{abstract}

The population in this study were clients and employees of PT. Surya Artha SRB Barokah Semarang . number of employees required sample is 45 people and the customer sample 99.88 or 100 people. The analytical method used is descriptive analysis .

Results of the study is a financial ratio used is ROA, ROA and LDR. Results of this study indicate that the SRB Surya Artha Barokah Semarang from 2010 through 2012 can achieve cost effectiveness and generate optimal profits . Performance of the financial perspective shows good results even continue experiencing good growth. Results of this study indicate that explains that the market share in Semarang Barokah Surya Artha SRB increased to reach an average value of $161.88 \%$. Surya Artha SRB Barokah Semarang maintain competitiveness, interest rates, increasing mastery of market segments in order to meet customer needs. Surya Artha SRB Barokah Semarang start expanding operations by expanding the branch network, the development of a variety of products and services offered. It aims to improve after-sales service and provide additional benefits to our customers in order to still have the loyalty of the BPRS Artha Barokah Surya Semarang . Results of measurements describing the success ratio AETR increased efficiency, effectiveness and accuracy of the transactions conducted BPRS Artha Barokah Surya Semarang. Results of this study showed improvement indicated that employee productivity is increasing every year. This happens because in assessing the percentage of successful employee training SRB Surya Artha Barokah Semarang . Regarding the level of employee satisfaction shows the value of the overall average score of 4.03 . The figure shows the results of a good or satisfied.

Keywords : financial perspective, customer perspective, internal business processes, learning and growt perspective 


\section{PENDAHULUAN}

Krisis ekonomi beberapa tahun yang lalu membuat kondisi perekonomian di Indonesia belum menunjukkan kemajuan yang pesat, sehingga menuntut para pemimpin atau manajemen perusahaan untuk meningkatkan daya saing dengan memberikan pelayanan yang terbaik bagi para konsumennya untuk mempertahankan kelangsungan hidupnya. Kunci persaingan dalam pasar global adalah kualitas total yang mencakup penekananpenekanan pada kualitas produk, kualitas biaya dan harga, kualitas pelayanan, kualitas estetika guna memberikan kepuasan terus-menerus sehingga tercipta pelanggan yang loyal (Hansen dan Mowen, 1999). Pengukuran kinerja tradisional lebih menekankan pada aspek keuangan sehingga mengabaikan fakta performance lain yang sebenarnya juga penting. Tujuan utama penelitian kinerja ini adalah untuk memotivasi personel dalam mencapai sasaran organisasi dalam memenuhi standar perilaku yang telah ditetapkan sebelumnya, sehingga membuahkan tindakan dan hasil yang diinginkan organisasi dengan menggunakan alat anlisis yang disebut Balanced Scorecard yang dikembangkan oleh Norton pada tahun 1992.

Berdasarkan uraian diatas, maka mengajukan penelitian skripsi dengan judul: "Analisis Penerapan Balanced Scorecard Sebagai Alat Pengukuran Kinerja (Studi Kasus: BPRS Artha Surya Barokah Semarang".

\section{TUJUAN PENELITIAN}

Tujuan penelitian ini adalah: a. Menganalisis pengukuran Balanced Scorecard ditinjau dari perspektiff keuangan pada kinerja BPRS Artha Surya Barokah.

b. Menganalisis pengukuran Balanced Scorecard ditinjau dari perspektif pelanggan pada kinerja BPRS Artha Surya Barokah.

c. Menganalisis pengukuran Balanced Scorecard ditinjau dari perspektif proses internal bisnis pada kinerja BPRS Artha Surya Barokah.

d. Menganalisis pengukuran Balanced Scorecard ditinjau dari perspektif pertumbuhan dan pembelajaran pada kinerja BPRS Artha Surya Barokah.

\section{TINJAUAN PUSTAKA \\ Pengertian Kinerja}

Kinerja adalah suatu tampilan keadaan secara utuh atas perusahaan selama periode waktu tertentu, merupakan hasil atau prestasi yang di pengaruhi oleh kegiatan operasional perusahaan dalam memanfaatkan sumber-sumber data yang dimiliki (Helfert, dalam Srimindarti, 2004).

\section{Pengukuran Kinerja dan Manfaat Pengukuran Kinerja}

Menurut Larry D. Stout (dalam Yuwono 2002) menyatakan bahwa pengukuran kinerja merupakan proses mencatat dan mengukur pencapaian pelaksanaan kegiatan dalam arah pencapaian misi (mission accomplishment) melalui hasil-hasil yang ditampilkan berupa produk, jasa ataupun suatu proses. Manfaat sistem pengukuran kinerja yang baik adalah sebagai berikut: 
1. Menelusuri kinerja terhadap harapan pelanggan sehingga akan membawa perusahaan lebih dekat pada pelanggannya dan membuat seluruh orang dalam organisasi terlihat dalam upaya memberi kepuasan kepada pelanggan.

2. Memotivasi pegawai untuk melakukan pelayanan sebagai bagian dari mata rantai pelanggan dan pemasok internal.

3. Mengidentifikasi berbagai pemborosan sekaligus mendorong upaya-upaya pengurangan terhadap pemborosan tersebut (redustion of waste).

\section{Pengertian Balanced Scorecard}

Balanced Scorecard memberikan suatu Framework, suatu bahasa untuk mengkomunikasikan pada seluruh pegawai tentang apa yang menjadi kunci sukses dimasa yang akan datang. Mulyadi dalam bukunya Balanced Scorecard: Alat Manajemen kontemporer untuk pelipatgandaan Kinerja Keuangan Perusahaan (2000), mendefinisikan balanced scorecard ke dalam dua istilah kata yaitu : (1) kartu skor (scorecard) dan (2) berimbang (balanced). Kartu skor adalah kartu yang digunakan untuk mencatat skor hasil kinerja seseorang dan merencanakan skor yang hendak dicapai atau yang diwujudkan personel di masa depan. Kata berimbang dimaksudkan untuk menunjukkan bahwa kinerja personel diukur secara berimbang dari dua aspek: keuangan dan non keuangan, jangka pendek dan jangka panjang, intern dan ekstern. Jadi, kartu personel yang digunakan untuk merencanakan kartu skor yang hendak diwujudkan di masa depan, personel tersebut harus mempertimbangkan keseimbangan antara pencapaian kinerja keuangan dan non keuangan, antara jangka pendek dan jangka panjang, serta antara kinerja yang bersifat intern dan kinerja yang bersifat eksternal.

Sedangkan menurut Amin Widjaja Tunggal (2000), mendefinisikan Balanced Scorecard sebagai berikut : "Balanced Scorecard adalah laporan akuntansi yang didalamnya terdapat empat faktor dari perusahaan agar perusahaan itu sukses yang pertama adalah kinerja financial, kepuasan pelanggan, proses internal bisnis, inovasi dan pembelajaran."

\section{Perspektif-perspektif Balanced Scorecard}

Balanced scorecard terdiri dari empat perspektif yaitu:

1. Perspektif Keuangan (Financial Perspective)

Menurut Kaplan dan Norton (2000), menyatakan bahwa "Dalam balanced scorecard perspektif keuangan tetap menjadi hal yang sangat penting, karena ukuran keuangan merupakan salah satu dari konsekuensi ekonomi yang terjadi disebabkan oleh keputusan dan tindakan ekonomi yang diambil". Pengukuran kinerja keuangan menunjukkan apakah perencanaan, implementasi, dan pelaksanaan, dari strategi memberikan perbaikan yang mendasar.

2. Perspektif Pelanggan (Customer Perspective)

Pada masa lalu seringkali perusahaan mengkonsentrasikan 
diri pada kemampuan internal dan kurang memperhatikan kebutuhan konsumen. Sekarang strategi perusahaan telah bergeser fokusnya dari internal ke eksternal. Jika suatu unit bisnis ini mencapai kinerja keuangan yang superior dalam jangka panjang, mereka harus menciptakan dan menyajikan suatu produk atau jasa yang bernilai dari biaya perolehannya. Dan suatu produk akan semakin bernilai apabila kinerjanya semakin mendekati atau melebihi dari apa yang diharapkan dan persepsikan konsumen (Heppy Julianto, 2000).

3. Perspektif Proses Bisnis Internal Dalam perspektif ini, perusahaan melakukan pengukuran terhadap semua aktivitas yang dilakukan oleh perusahaan, baik manajer maupun karyawan untuk menciptakan suatu produk yang dapat memberikan kepuasan tertentu bagi customer dan para pemegang saham. Dalam hal ini perusahaan berfokus pada tiga proses bisnis utama yaitu :

1. Inovasi

Menurut Kaplan dan Norton (2001) proses inovasi dibagi dalam dua bagian yang penting dan terpisahkan. Pertama, mengidentifikasi pasar dan yang kedua menciptakan produk atau jasa untuk memenuhi kebutuhan pasar tersebut karena sangat menentukan keberhasilan perusahaan khususnya dalam jangka panjang.

2. Proses Operasi
Proses Operasi adalah proses untuk membuat dan menyampaikan produk atau jasa yang meliputi proses pembuatan produk dan proses menyampaikan produk kepada konsumen.

3. Proses Layanan Purna Jual Proses ini merupakan jasa pelayanan pada pelanggan setelah penjualan. Olah jasa tersebut dilakukan termasuk didalamnya garansi dan aktivitas perbaikan, penggantian produk yang rusak dan yang dikembalikan, serta proses pembayaran, seperti administrasi kartu kredit (Kaplan dan Norton, 2000).

4. Perspektif Pertumbuhan dan Pembelajaran

Organisasi-organisasi negara maju semuanya telah sadar akan pentingnya peranan karyawan bagi kinerja organisasi. Mereka sadar bahwa modal manusia adalah asset utama. Rincian perspektif ini dibagi dalam tiga prinsip oleh Kaplan dan Norton (1996) yaitu:

1. Karyawan (people).

Tenaga kerja pada perusahaan dewasa ini dituntut untuk dapat berfikir kritis dan melakukan evaluasi terhadap proses dan lingkungan untuk dapat memberikan usulan perbaikan. Dalam kaitannya dengan sumber daya manusia ada tiga hal yang perlu ditinjau dalam penerapan Balanced Scorecard:

a. Tingkat kepuasan kerja Kepuasan kerja merupakan prakondisi 
dari tingkat produktifitas, tanggung jawab, kualitas, dan customer servise.

b. Retensi karyawan

Retensi karyawan adalah kemampuan perusahaan untuk mempertahankan karyawan-karyawan terbaiknya untuk terus berada dalam organisasinya.

c. Produktifitas karyawan Produktifitas karyawan merupakan hasil dari pengaruh agregat dari peningkatan keahlian dan moral, inovasi, perbaikan proses internal,tingkat kepuasan konsumen.

2. Kemampuan sistem informasi Peningkatan kualitas karyawan dan produktifitas karyawan juga dipengaruhi oleh akses terhadap system informasi yang dimiliki oleh perusahaan. Semakin mudah informasi yang didapat maka karyawan akan memiliki kinerja yang lebih baik. Pengukuran terhadap akses informasi yang dimiliki perusahaan dapat dilakukan dengan mengukur presentase ketersediaan mengenai biaya produksi dan lain-lain.

3. Motivasi, pemberian wewenang, dan pembatasan wewenang karyawan

Prosedur dan perbaikan rutinitas harus dilakukan karena karyawan yang sempurna dengan informasi yang berlimpah tidak akan memberikan kontribusi pada keberhasilan perusahaan apabila mereka tidak diberikan kebebasan untuk mengambil keputusan atau bertindak.

\section{Kerangka Pemikiran}

Kerangka konseptual
merupakan pondasi utama untuk
sepenuhnya proyek penelitian itu
ditujukan, hal ini merupakan jaringan
hubungan antar variabel yang secara
logis diterangkan dan dikembangkan
dari perumusan masalah yang telah
diidentifikasikan melalui proses
wawancara, observasi dan survey
literatur, (Mudrajad Kuncoro, 2003)

Kerangka
konseptual
merupakan pondasi utama untuk
sepenuhnya proyek penelitian itu ditujukan, hal ini merupakan jaringan hubungan antar variabel yang secara logis diterangkan dan dikembangkan dari perumusan masalah yang telah diidentifikasikan melalui proses wawancara, observasi dan survey literatur, (Mudrajad Kuncoro, 2003) 
Perspektif Keuangan

Menggunakan metode CAMEL:

1. Return On Asset (ROA)

2. Biaya Operasional terhadap Pendapatan Operasional (BOPO)

3. Loan to Deposit Ratio (LDR)

Perspektif Pelanggan

Menggunakan:

1. Pangsa Pasar

2. Kepuasan Pelanggan

3. Profitabilitas pelanggan

Perspektif Proses Bisnis Internal Menggunakan:

1. Rasio Operasi

Perspektif Pertumbuhan dan Pembelajaran Menggunakan:

1. Produktivitas Karyawan

2. Pelatihan Karyawan

3. Kepuasan Karyawan

Alternatif Penerapan Balanced

Scorecard

Kinerja Perusahaan Di Bank

\section{METODE PENELITIAN}

Penentuan Sampel

Populasi adalah gabungan dari seluruh elemen yang berbentuk peristiwa, hal atau orang yang memiliki karakteristik yang serupa yang menjadi pusat perhatian seorang peneliti, karena itu dipandang sebagai sebuah semesta penelitian

(Ferdinand, 2006).Populasi dalam penelitian ini adalah nasabah dan karyawan PT. BPRS Artha Surya Barokah Semarang. Sedangkan sampel jumlah sampel karyawan yang dibutuhkan adalah 45 orang dan sampel nasabah 99,88 atau 100 orang.

\section{Metode Analisis}

\section{Analisis kuantitatif}

Penilaian kinerja dengan menggunakan Balanced Scorecard yaitu perhitungan yang dilakukan menggunakan scoring. Untuk mengetahui presentase bobot nilai rasio-rasio keuangan dapat menggunakan acuan sesuai dengan standar ketentuan yang dikeluarkan oleh Bank Indonesia yaitu:

1. Return On Asset (ROA)

Skor nilai ROA ditentukan sebagai berikut:

a. Kurang dari $0 \%$, skor nilai $=$ 0

b. Antara $0 \%-1 \%$, skor nilai $=$ 80

c. Antara $1 \%-2 \%$, skor nilai $=$ 100

d. Lebih dari $2 \%$, skor nilai $=$ 90

2. Biaya Operasional terhadap Pendapatan Operasional (BOPO)

Skor nilai BOPO ditentukan sebagai berikut: 
a. Lebih dari $125 \%$, skor nilai $=0$

b. Antara 92\% - 125\%,skor nilai $=80$

c. Antara $85 \%-92 \%$, skor nilai $=100$

d. Kurang dari $85 \%$, skor nilai $=90$

3. Loan to Deposit Ratio (LDR)

Skor nilai LDR ditentukan sebagai berikut:

a. Kurang dari $50 \%$, skor nilai $=0$

b. Antara 50\% - 85\%, skor nilai $=80$

c. Antara $85 \%$ - $110 \%$, skor nilai $=100$

d. Lebih dari $110 \%$, skor nilai $=90$

\section{Analisis kualitatif}

Analisis kualitatif merupakan data yang dikategorikan tetapi tidak dapat dikuantitatifkan (J. Supranto, 1993).

a. Return On Asset (ROA)

Standar terbaik ROA menurut Bank Indonesia adalah 1,5\%. Variabel ini mempunyai bobot nilai $15 \%$. Misalnya suatu bank memiliki nilai ROA sebesar 1 , $87 \%$, maka skor akhir ROA adalah $15 \%$ x $100=15$.

b. Biaya Operasional terhadap Pendapatan Operasional (BOPO)

Standar terbaik BOPO menurut Bank Indonesia adalah $92 \%$. Variabel ini mempunyai bobot nilai sebesar $15 \%$. Misalnya suatu bank memiliki BOPO $86,44 \%$, maka skor akhir BOPO adalah $15 \%$ x $100=15$.

c. Loan to Deposit Ratio (LDR)

Standar terbaik LDR menurut Bank Indonesia adalah 85\% -
$110 \%$. Variabel ini diberi bobot nilai sebesar 20\%. Misalnya suatu bank memiliki LDR 86, 93\%, maka skor akhir LDR adalah $20 \%$ x $100=20$.

d. Uji Validitas

Digunakan untuk mengukur valid atau tidaknya suatu kuesioner. Suatu kuesioner dinilai valid apabila pertanyaan pada kuesioner mampu untuk mengungkapkan sesuatu yang akan diukur oleh kuesioner tersebut (Ghozali, 2006). Jika suatu alat ukur mempunyai korelasi signifikan antara skor item terhadap skor totalnya maka dikatakan skor tersebut tidak valid (Ghozali, 2006). Validitas data diukur dengan cara membandingkan $\mathrm{r}_{\text {hitung }}$ dengan $r_{\text {table }}$, jika:
a. $r_{\text {hitung }}>r_{\text {table }}$ maka variabel valid
b. $r_{\text {hitung }}<r_{\text {table }}$ maka variabel tidak valid

e. Uji Reabilitas

Reliabilitas adalah alat untuk mengukur suatu kuesioner yang merupakan indikator dari variabel atau konstruk. Suatu kuesioner dikatakan reliable atau handal jika jawaban seseorang terhadap pertanyaannya adalah konsisten atau stabil dari waktu ke waktu. Uji reliabilitas dilakukan dengan menggunakan uji statistik Cronbach Alpha $(\alpha)$ dengan alat bantu program komputer SPSS for Windows. Menurut (Ghozali, 2006), suatu konstruk atau variabel dikatakan reliabel jika memberikan nilai Cronbach Alpha lebih besar dari 0,60 . 
Pengukuran kinerja perspektif

HASIL PENELITIAN DAN PEMBAHASAN

\section{Hasil Penilaian Kinerja Perspektif Keuangan}

a. ROA keuangan BPRS Artha Surya

Barokah Semarang dengan konsep Balanced Scorecard dilakukan melalui tiga tolok ukur menggunakan rasio keuangan, antara lain:

\begin{tabular}{|c|c|c|c|}
\hline & Tahun 2010 & Tahun 2011 & Tahun 2012 \\
\hline Laba Bersih & $\mathrm{Rp} \quad 380.754 .000$ & $\mathrm{Rp} \quad 688.109 .000$ & $\mathrm{Rp} \quad 1.264 .070 .000$ \\
\hline Aktiva & Rp 13.029.084.000 & Rp 17.205.406.000 & $\operatorname{Rp} 26.500 .697 .000$ \\
\hline$\% \mathrm{ROA}$ & $2,92 \%$ & $3,99 \%$ & $4,76 \%$ \\
\hline
\end{tabular}

Sumber : Data sekunder yang diolah dari laporan tahunan, 2013

Hasil dari analisis ini adalah ROA pada BPRS Artha Surya Barokah Semarang tahun 2010 sebesar $2,92 \%$, di tahun 2011 meningkat menjadi $3,99 \%$ dan tahun 2012 naik menjadi $4,76 \%$. Dengan adanya kenaikan ROA pada tahun 2011 menunjukkan bahwa semakin besar mendapatkan tingkat keuntungan yang dapat dicapai BPRS Artha Surya Barokah Semarang. Ketentuan Bank Indonesia menyatakan bahwa standar terbaik ROA adalah $\geq$ $1,215 \%$, maka dalam hal ini BPRS Artha Surya Barokah Semarang berada pada kondisi sehat.

\section{b. Rasio Efisiensi (BOPO)}

\begin{tabular}{|l|c|c|c|}
\hline & Tahun 2010 & Tahun 2011 & Tahun 2012 \\
\hline Biaya Operasional & $\operatorname{Rp~} 1.979 .802 .000$ & $\operatorname{Rp~} 1.557 .456 .000$ & $\operatorname{Rp~} 1.184 .172 .000$ \\
\hline $\begin{array}{l}\text { Pendapatan } \\
\text { Operasional }\end{array}$ & $\operatorname{Rp~} 4.171 .537 .000$ & $\mathrm{Rp} 2.903 .289 .000$ & $\mathrm{Rp} 1.973 .727 .000$ \\
\hline \% BOPO & $47,45 \%$ & $53,64 \%$ & $59,96 \%$ \\
\hline Rata-rata & \multicolumn{3}{|c|}{$53,68 \%$} \\
\hline
\end{tabular}

Sumber: Data sekunder yang diolah dari laporan tahunan, 2013

Hasil dari tabel 4.3 menunjukkan bahwa BOPO pada tahun 2010 sebesar $47,45 \%$ dan meningkat menjadi 53,64\% tahun 2011. Kemudian pada tahun 2012 meningkat menjadi $59,96 \%$. Hal ini menandakan bahwa semakin tinggi nilai BOPO maka semakin buruk kualitasnya. Tetapi jika mengacu pada ketentuan Bank Indonesia menyatakan bahwa standar terbaik BOPO adalah $\leq 93,52 \%$, dalam hal ini BPRS Artha Surya Barokah Semarang masih berada pada kondisi sehat atau ideal. Hal ini dapat diartikan bahwa kemampuan bank dalam meningkatkan 
laba dan efisiensi usaha yang

dicapai.

c. Rasio Likuiditas (Loan to Deposit Ratio)

\begin{tabular}{|c|c|c|c|}
\hline & Tahun 2010 & Tahun 2011 & Tahun 2012 \\
\hline Kredit yang diberikan & Rp 624.306.000 & $\operatorname{Rp} 1.040 .417 .000$ & $\operatorname{Rp} 3.271 .583 .000$ \\
\hline $\begin{array}{l}\text { Total dana pihak } \\
\text { ketiga }\end{array}$ & Rp 612.931.000 & Rp 2.432.810.000 & $\operatorname{Rp} 3.527 .464 .000$ \\
\hline$\%$ LDR & $1,85 \%$ & $42,76 \%$ & $92,74 \%$ \\
\hline Rata-rata & & $45,78 \%$ & \\
\hline
\end{tabular}

Sumber: Data sekunder yang diolah dari laporan tahunan, 2013

Hasil dari tabel diatas menunjukkan bahwa pada tahun 2010 rasio LDR sebesar $1,85 \%$, tahun 2011 meningkat sebesar $42,76 \%$ dan tahun 2012 menjadi 92,74\%. Mengacu pada ketentuan Bank Indonesia, standar terbaik LDR adalah $\leq 94,75 \%$, hal ini menandakan bahwa BPRS Artha Surya Barokah Semarang berada pada posisi sehat.

\section{Hasil Penilaian Kinerja Perspektif Pelanggan}

\section{a. Pangsa Pasar (Market share)}

\begin{tabular}{|l|l|l|l|}
\hline & Tahun 2010 & Tahun 2011 & Tahun 2012 \\
\hline $\begin{array}{l}\text { BPRS Artha Surya } \\
\text { Barokah Semarang }\end{array}$ & Rp 13.029.084.000 & Rp 17.205.406.000 & Rp 26.500.697.000 \\
\hline Bank Swasta Nasional & $\mathrm{Rp} \mathrm{36.634.131.000}$ & $\mathrm{Rp} \mathrm{44.155.594.000}$ & $\mathrm{Rp} \mathrm{49.023.300.000}$ \\
\hline \% pangsa pasar & $35,56 \%$ & $38,96 \%$ & $54,05 \%$ \\
\hline Rata-rata & $42,85 \%$ & & \\
\hline
\end{tabular}

Sumber : Data sekunder diolah dari laporan statistik daerah se-Jawa

Tengah, 2013

$$
\text { Pada tahun } 2010
$$
sebesar 35,56\% dan tahun 2011 mengalami kenaikan $38,96 \%$. Kemudian naik menjadi $54,05 \%$ pada tahun 2012 serta nilai rata-rata keseluruhan mencapai 42,85\%. Hal ini menunjukkan bahwa BPRS Artha Surya Barokah Semarang terus menekankan daya saing, suku bunga serta meningkatkan kualitas produk dan jasa guna memberikan kepuasan terhadap nasabah. b. Kepuasan (Nasabah)

Data yang diperoleh dari survey penyebaran kuesioner kepada nasabah BPRS Artha Surya Barokah Semarang dengan menggunakan Skala Likert 5 point, menunjukkan hasil nilai rata-rata keseluruhan sebesar 3,97. Angka yang dihasilkan dari nilai rata-rata ini menginterpretrasikan bahwa angka diatas 3.50 memiliki penilaian dengan 
kategori cukup baik atau cukup puas. Terkait penilaian tersebut, BPRS Artha Surya Barokah Semarang akan berusaha memberikan pelayanan terbaik. Hal ini bertujuan untuk mempertahankan loyalitas kepada nasabah serta meningkatkan pencapaian nasabah baru.

\section{c. Profitabilitas Konsumen}

\begin{tabular}{|l|c|c|c|}
\hline & Tahun 2010 & Tahun 2011 & Tahun 2012 \\
\hline $\begin{array}{l}\text { Laba Bersih } \\
\text { Sebelum Pajak }\end{array}$ & Rp 446.305.000 & Rp 806.574 .000 & Rp 1.481.693.000 \\
\hline Penjualan Bersih & Rp 3.518.576.000 & Rp 4.980.862.000 & Rp 6.828.404.000 \\
\hline $\begin{array}{l}\text { \%Profitabilitas } \\
\text { Konsumen }\end{array}$ & $12,68 \%$ & $16,19 \%$ & $21,69 \%$ \\
\hline Rata-rata & \multicolumn{3}{|c|}{$16,85 \%$} \\
\hline
\end{tabular}

Sumber: Data sekunder yang diolah dari laporan tahunan, 2013

Hasil ini menjelaskan bahwa persentase profitabilitas konsumen pada tahun 2010 sebesar $12,68 \%$ serta tahun 2011 meningkat menjadi $16,19 \%$ dan meningkat kembali menjadi 21,69\% pada tahun 2012. Meskipun nilai rata-rata masih dibawah nilai persentase profitabilitas konsumen tahun 2012, namun nilai rata-rata tetap lebih besar dibanding nilai persentase profitabilitas konsumen tahun sebelumnya. Jadi semakin tinggi nilai profitabilitas konsumen, berarti menunjukkan semakin tinggi laba yang berhasil dicapai oleh perusahaan.

\section{Hasil Penilaian Kinerja} Perspektif Bisnis Internal

Untuk mengetahui efisiensi dan efektivitas serta ketepatan proses transaksi yang dilakukan BPRS Artha Surya Barokah Semarang, perhitungan dapat dilakukan dengan menggunakan rasio AETR dibawah ini:

\begin{tabular}{|l|l|l|c|}
\hline & Tahun 2010 & Tahun 2011 & Tahun 2012 \\
\hline Biaya Administrasi & Rp 324.622.000 & $118.437 .777,59$ & $172.091 .438,94$ \\
\hline Total Pendapatan & Rp 3.518.576.000 & $203.409 .017,25$ & $276.430 .939,54$ \\
\hline \% Rasio AETR & $9,22 \%$ & $9,67 \%$ & $7,01 \%$ \\
\hline Rata-rata & \multicolumn{3}{|c|}{$8,63 \%$} \\
\hline
\end{tabular}

Sumber: Data sekunder yang diolah dari laporan tahunan, 2013

Hasil dari tabel diatas menjelaskan bahwa selama periode tahun 2010-2012 mengalami peningkatan dengan nilai rata-rata keseluruhan $8,63 \%$. Hal ini menunjukkan bahwa BPRS Artha Surya Barokah Semarang berhasil 
melakukan kegiatan penataan jaringan operasional untuk meningkatkan pelayanan nasabah. Hal ini menunjukkan bahwa adanya peningkatan efisiensi, efektivitas serta ketepatan proses transaksi yang dilakukan BPRS Artha Surya
Barokah Semarang. Pengembangan produk dan jasa yang ditawarkan, peningkatan pelayanan purna jual, pengembangan kerjasama yang dilakukan BPRS Artha Surya Barokah Semarang dengan Bank lainnya meningkat lebih baik.

\section{Hasil Penilaian Kinerja Perspektif Pertumbuhan dan Pembelajaran}

\section{a. Produktivitas Karyawan}

\begin{tabular}{|l|l|l|l|}
\hline & \multicolumn{1}{|c|}{ Tahun 2010 } & \multicolumn{1}{c|}{ Tahun 2011 } & Tahun 2012 \\
\hline Laba Bersih Sebelum Pajak & 446.305 .000 & 806.574 .000 & 1.481 .693 .000 \\
\hline Karyawan Keseluruhan & 35 & 40 & 45 \\
\hline Total & $12.751 .571,42$ & 20.164 .350 & $32.926 .511,11$ \\
\hline Rata-rata & \multicolumn{3}{|c|}{$21.947 .477,51$} \\
\hline
\end{tabular}

Sumber : Data sekunder yang diolah dari laporan tahunan, 2013

Dari tabel diatas menunjukkan bahwa produktivitas karyawan pada tahun 2010 adalah $\mathrm{Rp}$ 12.751.571,42 artinya setiap karyawan memberikan bagian laba bersih kepada perusahaan sebesar $\mathrm{Rp}$ 12.751.571,42. Sedangkan pada tahun 2011 mengalami kenaikan sebesar $\mathrm{Rp}$ 20.164.350 dan pada tahun
2012 meningkat sebesar Rp 32.926.511,11. Jumlah produktivitas karyawan pada tahun 2012 lebih besar dari jumlah rata-rata produktivitas selama tiga tahun. Hasil tersebut mengindikasikan bahwa karyawan telah mengalami peningkatan produktivitas setiap tahun.

b. Tingkat Persentase Pelatihan Karyawan

\begin{tabular}{|l|c|c|c|}
\hline & Tahun 2010 & Tahun 2011 & Tahun 2012 \\
\hline Karyawan yang ditraining & 4 & 5 & 7 \\
\hline Total Karyawan & 40 & 45 & 50 \\
\hline \% Karyawan yang terampil & $10 \%$ & $11,11 \%$ & $14 \%$ \\
\hline Rata-Rata & \multicolumn{3}{|c|}{$11,70 \%$} \\
\hline
\end{tabular}

Sumber : Data sekunder yang diolah dari laporan tahunan, 2013

Hasil dari tabel 4.12 dapat dilihat bahwa tingkat persentase karyawan yang terampil pada tahun 2010 sebesar 10\%. Peningkatan berturut-turut terjadi pada tahun 2011 yaitu $11,11 \%$ dan tahun 2012 meningkat menjadi 14\%. Hal ini merupakan keberhasilan BPRS Artha Surya Barokah Semarang dalam mengembangkan Sistem Manajemen Sumber Daya Manusia yang Berbasis Kompetensi (MSDM-BK). 
Program Pendidikan dan Pelatihan diberikan guna meningkatkan kualitas SDM yang kompeten.

\section{c. Tingkat \\ Karyawan}

Kepuasan

Data yang diperoleh

dari survey penyebaran

kuesioner kepada karyawan

BPRS Artha Surya Barokah

Semarang menunjukkan hasil

nilai rata-rata keseluruhan

sebesar 4,03. Angka tersebut menunjukkan hasil dengan kategori puas atau baik karena memiliki nilai ratarata diatas 4.00. Berkaitan dengan penilaian tersebut, keberhasilan BPRS Artha Surya Barokah Semarang terwujud karena didukung dengan penerapan teori model Porter-Lawler yang baik.

\section{PENUTUP}

\section{Kesimpulan}

\section{Perspektif Keuangan}

Rasio keuangan yang digunakan adalah ROA, BOPO dan LDR. Hasil penelitian ini menunjukkan bahwa BPRS Artha Surya Barokah Semarang dari tahun 2010 hingga tahun 2012 dapat mencapai cost effectiveness dan menghasilkan laba perusahaan yang optimal. Kinerja pada perspektif keuangan menunjukkan hasil yang baik bahkan terus mengalami perkembangan yang baik.

\section{Perspektif Pelanggan}

Hasil dari penelitian ini menjelaskan bahwa pangsa pasar, kepuasan pelanggan dan profitabilitas pelanggan pada BPRS Artha Surya Barokah Semarang mengalami peningkatan pada tiap tahunnya.

\section{Perspektif Bisnis Internal}

BPRS Artha Surya Barokah

Semarang mulai memperluas jaringan operasional dengan cara memperluas jaringan kantor, pengembangan berbagai produk dan jasa yang ditawarkan. Hal ini bertujuan untuk meningkatkan layanan purna jual dan memberikan tambahan manfaat kepada para nasabah agar tetap mempunyai loyalitas terhadap BPRS Artha Surya Barokah Semarang. Hasil dari pengukuran rasio AETR menggambarkan keberhasilan peningkatan efisiensi, efektivitas serta ketepatan proses transaksi yang dilakukan BPRS Artha Surya Barokah Semarang.

\section{Perspektif Pertumbuhan dan} Pembelajaran

Hasil dari penelitian ini menunjukkan peningkatan yang mengindikasikan bahwa produktivitas karyawan terus mengalami peningkatan setiap tahunnya. Hal ini terjadi karena dalam mengukur tingkat persentase pelatihan karyawan berhasil dilakukan BPRS Artha Surya Barokah Semarang. Mengenai tingkat kepuasan karyawan menunjukkan nilai skor rata-rata keseluruhan 4,03. Angka tersebut menunjukkan hasil yang baik atau puas.

\section{DAFTAR PUSTAKA}

Ferdinand. 2006. Metode Penelitian Bisnis Untuk Akuntansi dan Manajemen. Yogyakarta: BPFE. 
Ghozali, Imam. 2006. Aplikasi Analisis Multivariate Dengan Program SPSS. Semarang: Badan Penerbit Undip.

Hansen and Mowen. 1999. Management Accounting. International Thompson Publishing, Ohio.

Julianto, Heppy. 2000. Mengukur Kepuasan Pelanggan. Manajemen, No. 138, Februari.

Kaplan, Robert S, dan David P, Norton. 1996. Using the Balnced Scorecard as a Strategic Management System. Harvard Business Review. January-Pebruary.

Kaplan, Robert S, dan David P, Norton. 2000. Balanced Scorecard Menerjemah Strategi Menjadi Aksi. Jakarta: Erlangga.

Kaplan, Robert S, dan David P, Norton. 2001. The Strategy Focused Organization. Harvard Business Press.

Kuncoro, Mudrajad. 2003. Metode Riset Untuk BIsnis dan Ekonomi. Jakarta: Erlangga

Mulyadi. 2000. Alat manajemen Kontemporer untuk Melipatgandakan Kinerja Perusahaan Balanced Scorecard. Jakarta: Salemba Empat.

Supranto, J. 1993. Pengantar Akuntansi Syari'ah. Jakarta: Salemba Empat.
Tunggal, A. Widjaja. 2000. Pokopoko Balanced Scorecard. Jakarta: Harvindo.

Yuwono, Sony. 2002. Petunjuk Praktis Penyusunan Balanced Scorecard Menuju Organisasi Yang Berfokus Pada Strategi. Jakarta: PT. Gramedia Pustaka Utama. 